\title{
TSG101 wt Allele
}

National Cancer Institute

\section{Source}

National Cancer Institute. TSG101 wt Allele. NCI Thesaurus. Code C52250.

Human TSG101 wild-type allele is located in the vicinity of 11 p15 and is approximately 47 $\mathrm{kb}$ in length. This allele, which encodes tumor susceptibility gene 101 protein, plays a role in endocytosis. The allele is essential for the sorting of endocytic vesicles. 